\title{
Deteksi Dini, Faktor Risiko, dan Dampak Perlakuan Salah pada Anak
}

\author{
Daisy Widiastuti, Rini Sekartini
}

\begin{abstract}
Child abuse atau kekerasan pada anak merupakan keadaan yang sering kita jumpai pada kehidupan sehari-hari, fenomena gunung es berlaku pada keadaan tersebut, data pasti mengenai child abuse sulit diperoleh. Kekerasan terhadap anak termasuk semua bentuk perlakuan menyakitkan baik fisik, seksual maupun emosional yang dilakukan orang tua atau orang lain dalam konteks hubungan tanggung jawab atau kekuasaan. Faktor resiko baik pada anak, orang tua/situasi keluarga maupun masyarakat/sosial mempunyai hubungan dengan dugaan kekerasan pada anak. Wawancara terstruktur, pemeriksaan fisik yang cermat, dan pemeriksaan penunjang dapat membantu mengetahui kasus kekerasan pada anak. Kekerasan pada anak dapat memberikan dampak akut atau kronik bagi tumbuh kembang anak, terhadap keluarga dan masyarakat.
\end{abstract}

Kata kunci: child abuse, faktor resiko.

$\mathrm{P}$ ertumbuhan dan perkembangan anak yang optimal sangat dipengaruhi oleh peran serta orangtua, guru, pendidik, dan orang-orang lain yang berada di lingkungan sekitarnya. Kebutuhan anak yaitu pemberian asuh, asih, dan asah akan membuat mereka menjadi dewasa sumber daya yang potensial. Sebaliknya, perlakuan salah yang diberikan pada anak akan menghambat tumbuh kembang anak.

Child abuse pertama kali dilaporkan oleh Ambroise Tardieu, seorang ahli patologi dan kedokteran forensik, Perancis pada tahun $1860 .{ }^{1}$

\footnotetext{
Alamat korespondensi:

Dr. Rini Sekartini, Sp.A.

Divisi Tumbuh Kembang Pediatri Sosial. Departemen Ilmu Kesehatan Anak FKUI-RSCM.

Jl. Salemba no. 6, Jakarta 10430.

Telepon: 021-3160622. Fax.021-3913982

Dr. Daisy Widiastuti Peserta Program Studi Ilmu Kesehatan Anak FKUIRSCM, Jakarta.
}

John Caffey tahun 1946 menemukan fraktur pada anak dengan hematom subdural kronik, sering pula fraktur multipel dengan stadium penyembuhan yang bervariasi, yang dicurigai sebagai akibat perlakuan salah oleh orang tuanya. Pada tahun 1952 masyarakat lebih menaruh perhatian terhadap masalah perlakuan salah terhadap anak, setelah Henry Kempe menulis mengenai battered child syndrome dalam Journal of The American Medical Association. ${ }^{1,2}$

Meningkatnya kekacauan yang disertai kekerasan di berbagai daerah di Indonesia saat ini merupakan indikasi bahwa kekerasan tidak hanya terbatas di dalam rumah tangga, namun sudah meluas pada kelompok-kelompok masyarakat yang bertikai di wilayah yang bersangkutan. Pertikaian yang disertai kekerasan tidak hanya mengambil korban orang dewasa, namun juga anak-anak. Dalam situasi tidak menentu dan serba kekurangan, penegakan dan perlindungan hukum amat minim, sehingga umumnya orang dewasa akan mengalami stres. Berbagai situasi yang menimbulkan frustasi seperti 
kesulitan ekonomi, rasa khawatir mengenai pekerjaan, kesulitan pekerjaan, pertengkaran dengan pasangan, kelelahan fisik, dapat menjadi sumber stres yang membuat orang dewasa menjadi lebih mudah melakukan tindak kekerasan. ${ }^{3}$ Catatan dari Yayasan Kesejahteraan Anak Indonesia (YKAI) menunjukkan adanya peningkatan kasus dalam kurun waktu tiga tahun, 172 kasus pada tahun 1994, 421 kasus pada tahun 1995, dan 476 kasus pada tahun 1996. ${ }^{3}$ Data yang didapat pada Instalasi Gawat Darurat RSCM Jakarta/Pusat Krisis Terpadu, sejak bulan Juni 2000 hingga Juni 2003 terdapat 720 kasus anak yang mengalami perlakuan salah.

\section{Definisi}

Perlakuan salah meliputi perbuatan ataupun penelantaran yang mengakibatkan morbiditas dan mortalitas. ${ }^{4}$ Peraturan perundang-undangan di Indonesia belum memberikan definisi ataupun pengertian atas istilah child abuse dalam bahasa Indonesia. Berdasarkan salah satu kepustakaan istilah child abuse dalam bahasa Indonesia disebut sebagai kekerasan terhadap anak. ${ }^{4}$ Pengertian kekerasan terhadap anak adalah (child abuse) adalah semua bentuk perlakuan menyakitkan secara fisik ataupun emosional, penyalahgunaan seksual, pelalaian, eksploitasi komersial atau eksploitasi lain, yang mengakibatkan cedera/kerugian nyata ataupun potensial terhadap kesehatan anak, kelangsungan hidup anak, tumbuh kembang anak, atau martabat anak, yang dilakukan dalam konteks hubungan tanggung jawab, kepercayaan, atau kekuasaan. ${ }^{4}$

\section{Faktor risiko}

Faktor risiko adalah faktor-faktor yang dapat berkontribusi untuk terjadinya suatu masalah atau kejadian. Variabel dalam faktor risiko secara bermakna mempunyai asosiasi dengan hasil akhir yang buruk.

Faktor-faktor risiko terhadap kejadian child abuse dapat ditinjau dari 3 aspek yaitu faktor sosial, orang tua dan anak.

1. Faktor masyarakat/ sosial, yaitu tingkat kriminalitas yang tinggi, layanan sosial yang rendah, kemiskinan yang tinggi, tingkat pengangguran yang tinggi, adat istiadat mengenai pola asuh anak, pengaruh pergeseran budaya, stres pada para pengasuh, budaya memberikan hukuman badan kepada anak, dan pengaruh media massa.

2. Faktor orang tua atau situasi keluarga, yaitu riwayat orang tua dengan kekerasan fisik atau seksual pada masa kecil, orang tua remaja, imaturitas emosi, kepercayaan diri rendah, dukungan sosial rendah, keterasingan dari masyarakat, kemiskinan, kepadatan hunian (rumah tinggal), masalah interaksi dengan masyarakat, kekerasan dalam rumah tangga, riwayat depresi dan masalah kesehatan mental lainnya (ansietas, skizoprenia), mempunyai banyak anak balita, riwayat penggunaan zat/ obatobatan terlarang (NAPZA) atau alkohol, kurangnya dukungan sosial bagi keluarga, diketahui ada riwayat child abuse dalam keluarga, kurang persiapan menghadapi stres saat kelahiran anak, kehamilannya disangkal, orang tua tunggal, riwayat bunuh diri pada orang tua/ keluarga, pola mendidik anak, nilai-nilai hidup yang dianut orangtua, dan kurang pengertian mengenai perkembangan anak.

3. Faktor anak, yaitu, prematuritas, berat badan lahir rendah, cacat, dan anak dengan masalah/ emosi.

Menurut Bittner dan Newberger perlakuan salah pada anak disebabkan faktor-faktor multidimensi (Gambar 1).

Perlakuan salah terhadap anak, dibagi menjadi dua golongan, yaitu ${ }^{1}$ dalam keluarga (perlakuan salah fisis, perlakuan salah seksual, perlakuan salah emosional, penelantaran anak, dan sindrom Munchausen) dan di luar keluarga (dalam institusi/lembaga, tempat kerja, jalan, medan perang).

\section{Diagnosis}

Diagnosis perlakuan salah terhadap anak sukar karena kebanyakan orang tua tidak mengaku bahwa trauma terjadi akibat dari perlakuannya. Mereka berusaha mengarang cerita tentang bagaimana trauma tersebut terjadi, bahkan ada yang marah- 


\section{FAKTOR SOSIO-KULTURAL}

- Norma/nilai yang ada dimasyarakat

- Hubungan antar manusia

- Kemajuan zaman: pendidikan, hukum hiburan, olahraga, kesehatan.

Stres berasal dari anak

Stres berasal dari keluarga

- Kemiskinan, pengangguran, mobilitas, isolasi, perumahan, tidak memadai

- Hubungan orang tua-anak, stres perinatal, anak yang tidak diharapkan, prematuritas

- Perceraian
- $\quad$ Fisik berbeda (misal cacat)

- Mental berbeda (misal retardasi)

- Temperamen berbeda (misal sukar)

- Tingkah laku berbeda (misal hiperaktif)

- Anak angkat/tiri

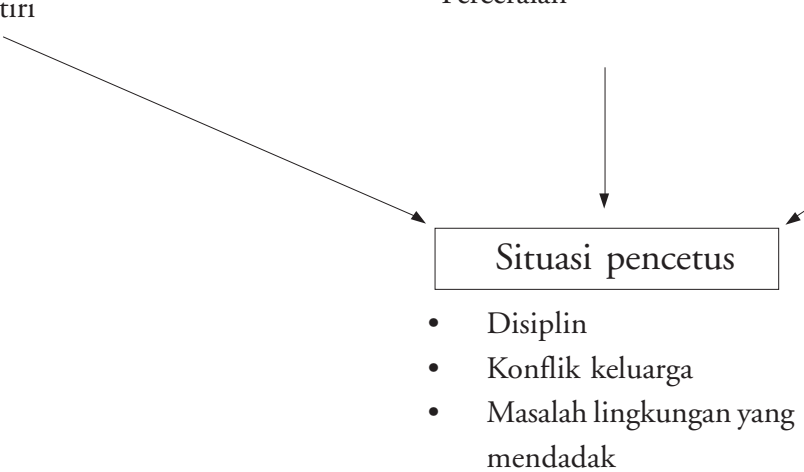

mendadak
Stres berasal dari orang tua

- $\quad$ Rendah diri

- Waktu kecil dapat perlakuan salah

- Depresi

- Harapan pada anak yang tak realistik

- Kelainan karakter/gangguan jiwa

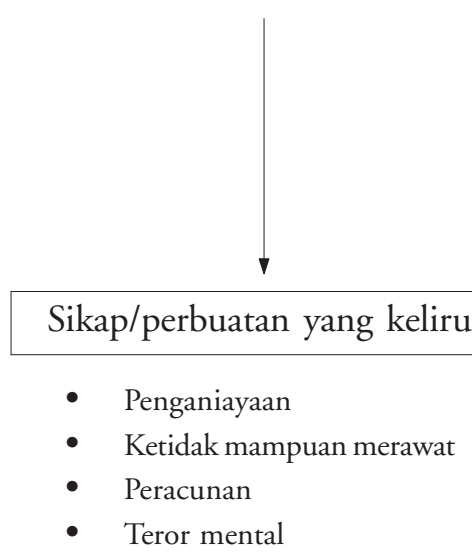

Gambar 1. Faktor-faktor risiko penyebab perlakuan salah pada anak ${ }^{1}$ 
marah atau bicara sekedarnya saja pada saat dilakukan anamnesis. Oleh karena itu sehingga diperlukan anamnesis dari orang - orang yang tinggal di sekitar keluarga tersebut, dan dituntut kecermatan dalam pemeriksaan, karena seringkali terlambat dilaporkan. ${ }^{1}$ Untuk melihat perlakuan salah terhadap anak, kita harus mengetahui umur dan tingkat perkembangan anak saat kejadian dialami, pengalaman anak dalam menghadapinya dan seluruh lingkungan emosi dari keluarganya. Diagnosis perlakuan salah terhadap anak memerlukan pendekatan multi disiplin yaitu riwayat penyakit, pemeriksaan fisis dan mental, laboratorium, dan radiologi.

\section{Perlakuan salah fisis}

Anamnesis: bila dijumpai satu atau lebih indikator pada anamnesis, dapat dipikirkan adanya child abuse pada anak.

- Riwayat kecelakaan tidak cocok dengan jenis atau beratnya trauma. Misalnya distribusi atau jenis lesi tidak sesuai dengan riwayat kejadian yang diceritakan atau riwayat kejadian menyatakan trauma ringan tetapi dijumpai trauma yang berat.

- Riwayat bagaimana kecelakaan terjadi tidak jelas atau pengasuh (orang tua) tidak tahu bagaimana terjadinya kecelakaan.

- Riwayat kecelakaan berubah-ubah ketika diceritakan kepada petugas kesehatan yang berlainan.

- Orang tua jika ditanya secara terpisah memberi keterangan yang saling bertentangan

- Riwayat yang tidak masuk akal, misalnya anak dikatakan terjatuh ketika memanjat padahal dudukpun belum bisa.

Pemeriksaan fisis: sering kali tidak ada kesesuaian antara pemeriksaan fisis dengan anamnesis tentang kejadian yang diungkapkan oleh orang tua atau pengantar. Pemeriksaan fisis harus dilakukan dengan teliti dan hati-hati terutama bila ditemukan jelas pada bagian-bagian tubuh yang tidak lazim.

Indikator kemungkinan terjadinya perlakuan salah fisis pada anak yaitu: ${ }^{3}$

- Memar dan bilur: pada wajah, bibir/mulut, bagian tubuh lainnya seperti di punggung, bokong, paha, betis; terdapat baik memar / bilur yang baru maupun yang sudah menyembuh; corak memar / bilur menunjukkan benda tertentu yang dipakai untuk kekerasan.

- Luka lecet dan luka robek: di mulut, mata, bibir, kuping, lengan dan tangan; di genitalia; luka akibat gigitan manusia; dan di bagian tubuh lain, terdapat luka baru atau berulang.

- Patah tulang: setiap patah tulang pada anak di bawah usia 3 tahun, patah tulang baru dan lama (dalam penyembuhan) yang ditemukan bersamaan, patah tulang ganda, patah tulang spiral pada tulang-tulang panjang lengan dan tungkai, dan patah tulang pada kepala, rahang dan hidung, serta patah gigi.

- Luka bakar: bekas sundutan rokok; luka bakar pada kaki, tangan, atau bokong, akibat kontak bagian tubuh tersebut dengan benda panas; dan bentuk luka yang khas sesuai dengan bentuk benda panas yang dipakai untuk menimbulkan luka tersebut.

- Cedera pada kepala: perdarahan (hematoma) subkutan dan atau subdural yang dapat dilihat pada foto rontgen, bercak/area kebotakan akibat tertariknya rambut, dan terdapat baik yang baru atau berulang.

- Lain-lain: dislokasi/lepas sendi pada sendi bahu atau pinggul (kemungkinan akibat tarikan), atau tanda-tanda luka yang berulang.

Pemeriksaan penunjang: berdasarkan anamnesis dan pemeriksaan fisis maka dapat dipilih jenis pemeriksaan laboratorium dan pencitraan yang akan dilakukan. Apabila dicurigai terdapat perdarahan maka evaluasi terhadap faktor perdarahan dan koagulasi harus dilakukan. Uji toksikologi dapat dilakukan apabila terdapat gejala keracunan, demikian pula pemeriksaan laboratorium dapat dilakukan tergantung indikasi. ${ }^{5,6}$ Pencitraan memegang peran penting dalam menegakkan diagnosis perlakuan salah fisis pada anak. Untuk anak yang berusia $<2$ tahun yang dicurigai telah mengalami perlakuan salah, American Association of Pediatrician (AAP) merekomendasikan dilakukannya survei tulang. ${ }^{6,7}$ Survei tulang meliputi foto rontgen anteroposterior untuk humerus, lengan bawah, tangan, pelvis, femur, tungkai bawah dan kaki, sedangkan foto rontgen lateral untuk toraks dan 
kepala. Beberapa modalitas pencitraan lainnya digunakan tergantung indikasi, seperti CT-scan yang merupakan pilihan terbaik untuk mengetahui trauma abdomen dan MRI untuk menilai cedera jaringan lunak kepala.

Tata laksana: terdiri dari tata laksana medis dan psikososial

- Tata laksana medis, penangananan masalah medis korban diutamakan terhadap keadaan yang mengancam jiwa, apabila perlu dilakukan konsultasi pada ahli pencitraan anak, bedah tulang, dan bedah plastik. ${ }^{6}$

- Tata laksana psikososial, dilakukan penanganan menyeluruh terhadap korban dan keluarganya, serta pelakunya. Tergantung dari berat ringannya masalah anak yang mengalami perlakuan salah fisis oleh orang tuanya. Untuk sementara anak dapat diasuh oleh lembaga perlindungan anak dan orang tua sebagai pelaku harus mendapat terapi psikologis. Masalah sosial dan masyarakat dapat dikurangi dengan bantuan lembaga terkait.

\section{Perlakuan Salah Seksual}

Anamnesis, sangat sulit untuk menggali cerita dari anak yang mengalami perlakuan salah walaupun terkadang dengan sendirinya mereka bercerita kepada orang tua atau dokter pemeriksanya tentang apa yang telah terjadi dan siapa yang melakukannya. Dalam usaha menggali cerita dapat digunakan alat bantu seperti ilustrasi gambar, boneka, maupun alat bantu lainnya. ${ }^{8}$ Pada anamnesis ditanyakan kembali identitas yang bersangkutan terutama umur dan perkembangan seks, kegiatan seksualnya selama dua minggu terakhir (hubungan seksual terakhir sebelum kejadian, siklus haid, haid terakhir dan apakah masih haid saat kejadian, waktu dan lokasi kejadian, ada tidaknya kekerasan sebelum kejadian, segala bentuk kegiatan seksual yang terjadi, termasuk ada tidaknya penetrasi, juga ditanyakan apa yang dilakukan korban setelah kejadian kekerasan seksual tersebut).

Pemeriksaan fisis, indikator kemungkinan terjadinya perlakuan salah pada anak, yaitu: ${ }^{3}$ adanya penyakit hubungan seksual, paling sering infeksi gonokokus; iInfeksi vaginal rekuren/berulang pada anak di bawah 12 tahun; rasa nyeri atau perdarahan dan atau keluarnya sekret dari vagina; gangguan dalam mengendalikan buang air besar atau buang air kecil; kehamilan pada usia remaja; cedera pada buah dada, bokong, dan perut bagian bawah, paha, sekitar alat kelamin atau dubur; pakaian dalam robek dan atau ada bercak darah pada pakaian dalam; ditemukan cairan mani/semen di sekitar mulut genital, anus, atau pakaian; rasa nyeri bila buang air besar dan buang air kecil; dan promiskuitas yang terlalu dini (precox).

Pemeriksaan penunjang, pengambilan sampel forensik harus dilakukan dalam waktu kurang dari 72 jam setelah kejadian. ${ }^{8}$ Sampel forensik yang diperiksa meliputi serpihan kulit, rambut, semen, sperma, dan darah. Adanya informasi penggunaan kondom atau cairan lubrikasi serta apakah korban telah makan, mandi/membersihkan diri, berkemih maupun berdefekasi setelah kejadian, akan menjadi data tambahan yang sangat berguna bagi bukti forensik. ${ }^{9}$ Pengambilan kultur dan pemeriksaan darah serologis terhadap penyakit menular seksual tergantung pada kemungkinan telah terjadinya penetrasi, gejala yang ada, dan angka kejadian penyakit menular seksual setempat.

Tata laksana, penentuan jenis tata laksana dilakukan berdasarkan jenis penganiayaan, usia anak, serta jangka waktu kejadian. Secara medis, terapi antibiotik profilaksis terhadap penyakit menular seksual pada anak yang mengalami perlakuan salah masih kontroversial. 8,9 Terapi spesifik diberikan apa bila pada pemeriksaan laboratorium darah menunjukkan hasil yang positip. ${ }^{9}$ Secara psikososial, gejala depresi, gangguan cemas, gangguan pasca trauma dan gangguan tingkah laku seksual sering dialami anak yang mengalami perlakuan salah seksual sehingga diperlukan penanganan terhadap korban maupun keluarga. Dokter sebagai penyedia pelayanan tingkat awal dapat melakukan rujukan ke lembaga perlindungan anak yang mempunyai fasilitas sosiopsikologis.

\section{Perlakuan Salah Emosional}

Anamnesis, anak yang mengalami perlakuan salah emosional dapat menyatakan dirinya telah diperlakukan salah, tetapi lebih sering anak menyangkal/ membalikkan cerita yang diungkapkan. Sering terdapat sikap ketakutan yang berlebihan terhadap orang tua, 
serta ada rasa enggan mendapat perlindungan dari orang tuanya.

Pemeriksaan fisis, pada waktu pemeriksaan fisis dilakukan, anak sering menghindari kontak mata, memperlihatkan sikap agresif, atau menarik diri secara berlebihan. Adanya perilaku ingin mencederai diri sendiri atau bunuh diri. Sangat mungkin ditemukan perilaku seksual agresif dan gangguan tidur. $^{10}$

Tata laksana, terapi psikologis merupakan terapi yang banyak diberikan kepada korban maupun pelaku. Dalam hal ini banyak digunakan terapi keluarga dan terapi interpersonal.

\section{Diagnosis Banding}

Beberapa keadaan atau penyakit yang dapat menyerupai akibat fisik perlakuan salah terhadap anak antara lain sebagai berikut:

\section{Kelainan pada kulit}

- Luka memar dibedakan dengan bercak mongolian. Bercak mongolian berwarna biru keabu-abuan pa warna merah. Luka memar selain akibat trauma juga harus dibedakan dengan hemofilia, anafilaktoid purpura, dan purpura fulminan.

- Eritema bila lokal, harus dibedakan dengan luka bakar, impetigo, nekrolisis epidermal toksika, selulitis bakterial, pioderma gangrenosa, reaksi fotosensitif, dll. Untuk membedakan perlu anamnesis perjalanan penyakit, kultur, pengecatan Gram, dan lainlain.

2. Kelainan pada tulang:

- Fraktur, selain karena trauma juga dapat sebagai akibat dari osteogenesis imperfekta, rikets, dan leukemia yang dapat meningkatkan insidens fraktur patologis, tetapi tidak mengenai metafisis.

- Lesi pada metafisis, selain karena trauma juga disebabkan oleh scurvy, lues, atau trauma lahir.

- Osifikasi subperiosteal, selain akibat trauma juga dapat karena keganasan, lues, osteoid osteoma, atau scurvy.
3. Sudden infant death syndrome (SIDS)

Sebagian besar penyebab SIDS tidak diketahui, tetapi SIDS juga dapat akibat trauma, asfiksia, infeksi botulinum, imunodefisiensi, aritmia jantung, dan hipoadrenalism.

4. Kelainan pada mata

- Perdarahan retina, selain akibat dari trauma kepala, juga karena penyakit gangguan perdarahan atau kanker ganas.

- Perdarahan konjuntiva, selain akibat trauma juga dapat karena batuk yang berat misalnya pada pertusis, konjungtivitis viral atau bakteri.

- Bengkak pada daerah orbita, selain akibat trauma juga selulitis daerah orbita/periorbita, epidural hematom, metastase kanker.

5. Hematuria, dapat terjadi akibat dari trauma, infeksi saluran urogenitalis, glomerulonefritis, dan lain lain

6. Akut abdomen, selain karena trauma dapat juga terjadi akibat dari kelainan pada sistem saluran pencernaan

\section{Dampak Child Abuse pada Tumbuh Kembang Anak}

Anak-anak tumbuh dan berkembang dengan baik bila mereka menerima segala kebutuhannya dengan optimal. Jika salah satu kebutuhan baik asuh, asih, maupun asah tidak terpenuhi maka akan terjadi kepincangan dalam tumbuh kembang mereka. Dampak yang terjadi dapat secara langsung maupun tidak langsung atau dampak jangka pendek dan dampak jangka panjang. Pertumbuhan dan perkembangan anak yang mengalami child abuse, pada umumnya lebih lambat dari pada anak yang normal yaitu,

- Dampak langsung terhadap kejadian child abuse $5 \%$ mengalami kematian, 25\% mengalami komplikasi serius seperi patah tulang, luka bakar, cacat menetap.

- Terjadi kerusakan menetap pada susunan saraf yang dapat mengakibatkan retardasi mental, masalah belajar/ kesulitan belajar, buta, tuli, masalah dalam perkembangan motor/ pergerakan 
kasar dan halus, kejadian kejang, ataksia, ataupun hidrosefalus.

- Pertumbuhan fisik anak pada umumnya kurang dari anak-anak sebayanya, tetapi Oates dkk pada tahun 1984 mengatakan bahwa tidak ada perbedaan yang bermakna dalam tinggi badan dan berat dengan anak normal.

- Perkembangan kejiwaan juga mengalami gangguan yaitu,

- Kecerdasan, berbagai penelitian melaporkan terdapat keterlambatan dalam perkembangan kognitif, bahasa, membaca, dan motorik. Retardasi mental dapat diakibatkan trauma langsung pada kepala, juga karena malnutrisi. Anak juga kurang mendapat stimulasi adekuat karena gangguan emosi.

- Emosi, masalah yang sering dijumpai adalah gangguan emosi, kesulitan belajar/sekolah, kesulitan dalam mengadakan hubungan dengan teman, kehilangan kepercayaan diri, fobia cemas, dan dapat juga terjadi pseudomaturitas emosi. Beberapa anak menjadi agresif atau bermusuhan dengan orang dewasa, atau menarik diri/menjauhi pergaulan. Anak suka mengompol, hiperaktif, perilaku aneh, kesulitan belajar, gagal sekolah, sulit tidur, temper tantrum.

- Konsep diri, anak yang mendapat kejadian child abuse merasa dirinya jelek, tidak dicintai, tidak dikehendaki, muram dan tidak bahagia, tidak mampu menyenangi aktifitas dan melakukan percobaan bunuh diri.

- Agresif, anak yang mendapat kejadian child abuse lebih agresif terhadap teman sebaya. Sering tindakan agresif tersebut meniru tindakan orang tua mereka atau mengalihkan perasaan agaresif kepada teman sebayanya sebagai hasil kurangnya konsep diri.

- Hubungan sosial, pada anak-anak tersebut kurang dapat bergaul dengan teman sebaya atau dengan orang dewasa, misalnya melempari batu, perbuatan kriminal lainnya.

- Akibat dari sexual abuse, tanda akibat trauma atau infeksi lokal, seperti nyeri perineal, sekret vagina, nyeri dan perdarahan anus; Tanda gangguan emosi, misalnya konsentrasi kurang, enuresis, enkopresis, anoreksia dan perubahan tingkah laku, kurang percaya diri, sering menyakiti diri sendiri, dan sering mencoba bunuh diri; Tingkah laku atau pengetahuan seksual anak yang tidak sesuai dengan umurnya.

\section{Kesimpulan}

Perlakuan salah pada anak merupakan masalah yang kompleks dan mempunyai spektrum klinis yang bervariasi. Tenaga medis sebagai tangan terdepan dalam menghadapi kasus perlakuan salah, sebaiknya memiliki keterampilan dalam deteksi dini, melakukan pertolongan gawat darurat, intervensi psikososial terhadap korban dan keluarganya, melakukan rujukan medik spesialistik dan psikososial. Peran dokter anak dalam penanganan kasus perlakuan salah dan penelantaran anak meliputi aspek medis dan aspek medikolegal. Penanganan kasus harus dilakukan oleh tim terpadu dari berbagai kalangan dan multi disiplin. Tenaga kesehatan mempunyai akses dengan lembaga-lembaga multi disiplin yang bergerak di bidang perlindungan anak.

\section{Daftar Pustaka}

1. Soetjiningsih. Perlakuan salah pada pada anak (child abuse). Dalam: Ranuh IGNG, penyunting. Tumbuh kembang anak. Jakarta: EGC, 1995. h. 165-75.

2. Jain MA. Emergency department evaluation of child abuse. Emerg Med Clin Nort Am 1999;17:575-93.

3. Widiatmoko W, Gunardi H, penyunting. Buku panduan tatalaksana kasus penganiayaan dan penelantaran anak. Jakarta: IDI, 2000. h. 1-64.

4. Fakih M, penyunting. Buku panduan pelatihan deteksi dini dan penatalaksanaan korban child abuse and neglect. Jakarta: IDI-UNICEF, 2003. h. 1-77

5. Pressel DM. Evaluation of physical abuse in children. Am Fam Physician 2000;6:3057-64.

6. Giardino AP. Child abuse and neglect: physical abuse. EMedicine Journal 2001;2:1-13.

7. American Academy of Pediatrics, Section on Radiology. Diagnostic imaging of child abuse. Pediatric 2000; 105:1345-8.

8. American Academy of Pediatrics, Committee on Child Abuse and Neglect. Guidelines for the evacuation of sexual abuse of children: subject review. Pediatrics 1999;103:186-91. 
9. Finkel MA, De Jong AR. Medical findings in child sexual abuse. Dalam: Reece RM, penyunting. Child abuse: medical diagnosis and management. Baltimore: William \& Wilkins, 1996. h. 185-247.
10. Hamarman S, Bernet W. Evaluating and reporting emotional abuse in children: parent-based, action-based focus aid in clinical decision -making. J Am Acad Child Adolesc Psychiatry 2000;39:1001-5. 